Рекомендована д. фрармац. наук, проф. С. М. Марчишин

УДК 615.322: 582.623.2:581.135.51

DOI 10.11603/2312-0967.2016.4.7124

\title{
ЕЛЕМЕНТНИЙ СКЛАД БРУНЬОК БАЛЬЗАМІЧНИХ ТОПОЛЬ, ЯКІ КУЛЬТИВУЮТЬ В УKPAÏHI
}

\author{
(c) А. М. Рудник \\ Національний фрармацевтичний університет, Харків
}

\begin{abstract}
Резюме: методом атомно-емісійної спектрографрії у бруньках п'яти видів бальзамічних тополь, які культивують в Україні, визначено вміст 19 елементів. В бруньках усіх видів за вмістом переважають К (925 - 1190 мг/100г), Са (530 - 655 мг/100г) та Mg (200 - 245 мг/100г). Найбільший вміст практично усіх елементів визначено у бруньках тополі волосистоплідної.
\end{abstract}

Ключові слова: родина вербові, рід тополя, бруньки, мікроелементи, макроелементи.

Вступ. Рід тополя (Populus) родини вербові (Salicaceae) у світовій фрлорі представлений близько 40 видами та численною кількістю гібридів як природного, так і штучного походження. На території України у дикій природі широко розповсюджені осика, тополя чорна та тополя біла. Проте для озеленення селищ і міст часто застосовують бальзамічні тополі та їх міжсекційні гібриди, які не утворюють «тополиного пуху», відзначаються морозостійкістю і особливою декоративністю [1].

Тополі відрізняються від інших деревних порід рядом цінних біологічних особливостей. По-перше, це виключно швидкий ріст (наприклад, для целюлозного виробництва стовбури тополі придатні вже у $15-20$, а ялина чи сосна - в 30 - 40 років), по-друге, здатність до легкого вегетативного (зимовими та літніми стебловими живцями, кореневими живцями та кореневими паростками, кілками, прищепленням) та насіннєвого розмноження і по-третє, це легка природна і штучна, внутрішньо- та міжвидова гібридизація [2]. Завдяки цьому види і гібриди роду тополя є основною культурою для вирощування енергетичної деревини. У Німеччині, Великобританії, Швеції та інших країнах Європи вже більш як 10 років біомасу тополь використовують для виготовлення біоетанолу та у вигляді пелетів для опалення будинків [3].

Бруньки бальзамічних тополь містять значну кількість френольних сполук (фрлавоноїди: піностробін, пінобаксин, хризин, галангін, апігенін; фенольні глікозиди: саліцин, популін, салікортин; гідроксикоричні кислоти (ферулову, коричну, хлорогенову, кофейну, n-кумарову; дубильні речовини), ефрірну олію від 0,37 до 4 \% основними компонентами якої $є$ біциклічні сесквітерпеноїди, органічні кислоти, полісахариди та ін. [4] і $є$ перспективною сировиною для створення нових препаратів антибактеріальної, протизапальної, аналгетичної дії.

Відомо, що рослини роду тополя є фрітоіндикаторами забруднення навколишнього середовища важки- ми металами, оскільки вирізняються особливою стійкістю до промислових викидів, здатністю до акумуляції важких металів без пошкодження рослини $[5,6,7]$. Доведена видоспецифічність накопичення тополями металів [6].

Раніше автором повідомлялось про особливості елементного складу бруньок, кори та листя тополі китайської (Populus simonii Carr.) [8].

Метою роботи стало вивчення складу і вмісту елементів у бруньках п'яти видів бальзамічних тополь, які культивують в Україні, для визначення особливостей накопичення елементів у різних видах та оцінки рівня техногенного забруднення сировини.

Методи дослідження. Об'єктами дослідження стали бруньки п'яти видів бальзамічних тополь: т. бальзамічної (P. balsamifera L.), т. лавролистої (P. laurifolia L.), т. волосистоплідної (P. trichocarpa Torr. Gray.), т. духмяної (P. suaveolens Fisch.), т. берлінської ( $P$. Чberolinensis Dipp.).

Сировину для досліджень заготовляли 3 дерев, що ростуть на околицях Муромського водосховища Харківської обл. (т. лавролиста) і в ботанічному саду Харківського національного університету імені В. Н. Каразіна (інші види). Збирали бруньки 3 молодих та багаторічних пагонів у квітні 2013 р., у період набубнявіння, не розподіляючи на вегетативні і генеративні. Зразки сировини висушували повітряно-тіньовим способом протягом 2 тижнів.

Наважки сировини, попередньо оброблені кислотою сульсратною, обвуглювали при нагріванні у муфрельній печі (температура не більш $500{ }^{\circ} \mathrm{C}$ ). Вивчення елементного складу тополі китайської проводили в ДНУ НТК «Інститут монокристалів» НАН України, використовуючи метод атомно-емісійної спектрограсрії із фротографрічною реєстрацією на приладі ДФС-8.

Результати й обговорення. В результаті аналізу у бруньках досліджуваних видів бальзамічних тополь було виявлено 19 елементів, із яких 5 віднесені до

ISSN 2312-0967. Фармацевтичний часопис. 2016. № 4 
макро-, 10 до мікро- та 4 до ультрамікроелементів. Отримані дані елементного складу досліджуваної сировини наведено в таблиці 1.

Дані таблиці 1 показують, що бруньки досліджуваних видів тополь мають однаковий елементний склад. Згідно зі зменшенням вмісту елемента у зразках сировини можна встановити наступний ряд: $\mathrm{K}<\mathrm{Ca}<\mathrm{Mg}<\mathrm{Si}<\mathrm{P}$ $<\mathrm{Na}<\mathrm{Al}<\mathrm{Fe}<\mathrm{Zn}<\mathrm{Mn}<\mathrm{Cu}<\mathrm{Sr}<\mathrm{Ni}<\mathrm{Pb}<\mathrm{Mo}$. Серед макроелементів за вмістом переважають К, його вміст коливається в межах від 925 до 1190 мг/100 г, Са (530 - 655 мг/100г), Mg (200 - 245 мг/100г); серед мікроелементів - Si (90 - 110 мг/100 г), Al (11,4 - 16,5 мг/100г), Fe $(7,6-12,0$ мг/100 г).
Вміст таких техногенних елементів, як Мо, Со, Pb - менший ніж 0,03 мг/100 г, As, Cd, Hg - менший ніж 0,01 мг/100 г. В усіх зразках вміст техногенних елементів знаходиться у межах вимог ДФУ [9].

Найбільший вміст практично всіх елементів спостерігається у бруньках тополі волосистоплідної. Слід зазначити, що вміст силіцію (основного елементу піску) виявився невисоким, хоча бруньки бальзамічних тополь вкриті липким бальзамом, що збільшує імовірність забруднення піском і пилом при заготівлі сировини. Отримані дані можуть буди використані для стандартизації сировини.

Таблиця 1. Елементний склад бруньок бальзамічних тополь

\begin{tabular}{|c|c|c|c|c|c|c|}
\hline \multirow{2}{*}{ № 3/п } & \multirow{2}{*}{ Елемент } & \multicolumn{5}{|c|}{ Вміст елементів, мг/100 г } \\
\cline { 2 - 6 } & & БТБ & БТЛ & БТВ & БТД & БТБер \\
\hline 1 & $\mathrm{Na}$ & 33 & 40 & 41 & 39 & 38 \\
\hline 2 & $\mathrm{~K}$ & 925 & 1120 & 1190 & 1130 & 1025 \\
\hline 3 & $\mathrm{Ca}$ & 530 & 640 & 655 & 625 & 610 \\
\hline 4 & $\mathrm{Mg}$ & 200 & 240 & 245 & 235 & 230 \\
\hline 5 & $\mathrm{P}$ & 56 & 68 & 70 & 66 & 65 \\
\hline 6 & $\mathrm{Si}$ & 90 & 105 & 110 & 105 & 100 \\
\hline 7 & $\mathrm{Fe}$ & 10,0 & 12,0 & 8,2 & 11,7 & 7,6 \\
\hline 8 & $\mathrm{Al}$ & 16,5 & 12,0 & 12,3 & 11,7 & 11,4 \\
\hline 9 & $\mathrm{Zn}$ & 3,3 & 4,0 & 4,1 & 3,9 & 3,8 \\
\hline 10 & $\mathrm{Cu}$ & 1,6 & 1,6 & 1,6 & 1,9 & 1,5 \\
\hline 11 & $\mathrm{Mn}$ & 3,3 & 4,0 & 4,1 & 3,9 & $<, 8$ \\
\hline 12 & $\mathrm{Mo}$ & $<0,02$ & $<0,02$ & $<0,02$ & $<0,02$ & $<0,02$ \\
\hline 13 & $\mathrm{~Pb}$ & $<0,03$ & $<0,03$ & $<0,03$ & $<0,03$ & $<0,03$ \\
\hline 14 & $\mathrm{Ni}$ & 0,66 & 0,80 & 0,41 & 0,78 & 0,76 \\
\hline 15 & $\mathrm{Sr}$ & 1,65 & 2,0 & 1,23 & 0,78 & $<1,14$ \\
\hline 16 & $\mathrm{Co}$ & $<0,03$ & $<0,03$ & $<0,03$ & $<0,03$ & $<0,03$ \\
\hline 17 & $\mathrm{Cd}$ & $<0,001$ & $<0,001$ & $<0,001$ & $<0,001$ & $<0,001$ \\
\hline 18 & $\mathrm{As}$ & $<0,001$ & $<0,001$ & $<0,001$ & $<0,001$ & $<0,001$ \\
\hline 19 & $\mathrm{Hg}$ & $<0,001$ & $<0,001$ & $<0,001$ & $<0,001$ & $<0,001$ \\
\hline
\end{tabular}

Примітки: БТБ - бруньки т. бальзамічної, БТЛ - бруньки т. лавролистої, БТВ - бруньки т. волосистоплідної, БТД бруньки т. духмяної, БТБер - бруньки т. берлінської.

Висновки. Методом атомно-емісійної спектрометрії визначили склад та вміст елементів у бруньках п'яти видів бальзамічних тополь, які культивують в Україні.

В усіх бруньках досліджуваних видів визначили однаковий елементний склад: не менше ніж 5 макро-, 10 мікро- та 4 ультрамікроелементи, вміст останніх був менший ніж 0,03 мг/100г.
У бруньках усіх видів переважають за вмістом К (925 - 1190 мг/100г), Са (530 - 655 мг/100г), Mg (200 $-245 \mathrm{мг/100г).}$

Встановлено, що найбільший вміст макроелементів спостерігається у бруньках тополі волосистоплідної. Вміст техногенних елементів знаходиться у межах вимог ДФУ. 


\section{Short message}

\section{Список літератури}

1. Консенсусный документ по биологии тополя Populus L. [Електронний ресурс]. - Режим доступу: http://www. oecd.org/science/biotrack/43479909.pdf.

2. Рудник А. М. Фармакогностичне дослідження бальзамічних тополь фрлори України : автореф. дис. на здобуття наук. ступеня канд. фрармац. наук. : спец. 15.00.02 / А. М. Рудник. - Харків, 2011. - 20 с.

3. Энергетические древесные культуры: ива и тополь. [Електронний ресурс]. - Режим доступу: http://ru-bio. ukrbio.com/ru/articles/8778/.

4. Бальзамічні тополі - перспективні лікарські рослини (огляд літератури) // А. М. Рудник, В. М. Ковальов, Н. В. Бородіна // Фітотерапія. Часопис. - 2008. - № 3. - С. 58-61.

5. Гиниятуллин Р. Х. Содержание некоторых металлов в листьях и ветвях Populus balsamifera L. в условиях промышленного загрязнения / Р. Х. Гиниятуллин, А. Ю. Кулагин, И. Р. Кагарманов // Екология. - 1998. № 2. - C. 94-97.
6. Гришко В. М. Акумуляція деяких важких металів тополями та особливості міграції елементів у системі «руннт - рослина» / В. М. Гришко, О. В. Данильчук // Інтродукція рослин. - 2007. - № 3. - С. 84-91.

7. Случик І. Й. Біологічна індикація забруднення довкілля важкими металлами з використанням Populus berolinensis Dipp. та Populus Simonii Carr. / І. Й. Случик, В. П. Стефрурак // Наукові записки Тернопільського державного педагогічного у-ту. Серія Біологія. - 1999. № 3 (6). - С. 57-60.

8. Вивчення мікроелементного складу Populus Simonii Carr. // А. М. Рудник, В. М. Ковальов, Н. В. Бородіна, Н В. Сидора // Запорожский медицинский журнал. 2008. - T. 2. - №2 (47). - С. 173-174.

9. Державна Фармакопея України / Держ. п-во «Український науковий фрармакопейний центр якості лікарських засобів». - 1-е вид. - Доповнення 3. - Х., 2009. - C. 198-199.

\section{ЭЛЕМЕНТНЫЙ СОСТАВ ПОЧЕК БАЛЬЗАМИЧЕСКИХ ТОПОЛЕЙ, КУЛЬТИВИРУЕМЫХ В УКРАИНЕ}

\section{А. М. Рудник}

Национальный фрармацевтический университет, Харьков

Резюме: методом атомно-эмиссионной спектрограсрии с фотографрической регистрацией в почках пяти видов бальзамических тополей, культивируемых в Украине, определено содержание 19 элементов. В почках всех видов преобладают по содержанию К (925 - 1190 мг/100г), Са (530 - 655 мг/100г), Mg (200 - 245 мг/100г). Наибольшее содержание практически всех элементов определено в почках тополя волосистоплодного.

Ключевые слова: семейство ивовые, род тополь, почки, макроэлементы, микроэлементы.

\section{ELEMENTARY CONSITUENS OF BALSAMIC POPLARS BUDS CULTIVATED IN UKRAINE}

\section{A. M. Rudnik \\ National University of Pharmacy, Kharkiv}

Summary: by the method of atomic-emission spectrography with photographic registration the content of 19 elements in the buds of five view of balsam poplars, which are cultivated in Ukraine, was determined. The content of K (925-1190 mg / $100 \mathrm{~g}$ ), Ca (530-655 mg / 100g), Mg (200-245 mg / $100 \mathrm{~g})$ in the buds of all view is dominated. The highest content of elements is defined in the Populus trichocarpa buds.

Key words: family Salicaceae, genus Populus, buds, macroelements, microelements. 